\title{
PERLINDUNGAN HUKUM TERHADAP PEMILIK RAHASIA DAGANG YANG BERSIFAT KOMERSIL
}

\author{
Susi Yanuarsi \\ Fakultas Hukum Universitas Palembang \\ susi.yanuarsi@gmail.com
}

\begin{abstract}
Normative trade secrets are formulated as information that is not known to the public in the field of technology and / or business that has economic value because they are useful in business activities, and are kept confidential by the owners of trade secrets. Ownership and protection of confidential information that is categorized as trade secrets and is an intangible asset of the company, occurs automatically. Whoever discovers or makes this trade secret, it is automatically by law that he is considered to be the owner and this owner has the right to use or complain given a permit made by everyone for commercial support purposes.
\end{abstract}

Keywords: legal protection, trade secrets, economic value

\begin{abstract}
Abstrak
Rahasia dagang secara normatif dirumuskan sebagai informasi yang tidak diketahui oleh umum dibidang teknologi dan/atau bisnis mempunyai nilai ekonomis karena berguna dalam kegiatan usaha, dan dijaga kerahasiannya oleh pemilik Rahasia dagang. Kepemilikan dan perlindungan atas suatu informasi rahasia yang dikategorikan sebagai rahasia dagang dan merupakan intangible aset dari suatu perusahaan, terjadi secara otomatis. Siapa yang menemukan atau membuat rahasia dagang tersebut, maka otomatis oleh undang-undang dialah dianggap sebagai pemiliknya dan pemilik ini berhak melarang penggunaan atau pengungkapan tanpa izinnya yang dilakukan seseorang kepada pihak ketiga untuk kepentingan yang bersifat komersial.
\end{abstract}

Kata kunci: perlindungan hukum, rahasia dagang, nilai ekonomis

I. PENDAHULUAN

A. Latar Belakang $\begin{array}{cr}\text { Perkembangan } & \text { ilmu } \\ \text { pengetahuan, teknologi dan }\end{array}$ informasi yang maju dengan pesat, mengakibatkan peningkatan persaingan dalam perdagangan. Keadaaan ini tidak saja menyangkut hak-hak individu dan badan hukum lainnya yang berada dalam lingkup nasional tetapi telah jauh menembus dinding dan batas teritorial suatu negara yang selanjutnya menyatu dengan pergaulan hukum dalam dunia perdagangan

internasional. Informasi dengan mudah dapat diakses melalui tehnologi yang canggih atau perangkat otomatisasi seperti internet, komputer, mesin faksimile, scanner dan foto copy, telah memberikan jalan yang sangat mudah untuk mencuri dan mengembangkan suatu informasi rahasia. Oleh karena itu informasi rahasia yang merupakan sumber pasokan dan komoditi berharga serta menjadi tumpuan kegiatan industri dan komersial telah dijadikan sebagai aset perusahaan dan dijaga ketat kerahasiaan nya oleh pemilik informasi. Akan tetapi informasi-informasi ini belum tentu merupakan informasi yang dikategorikan sebagai rahasia dagang. Dalam Black's Law 
Dictionary. ${ }^{1}$ yang dikategori- kan sebagai rahasia dagang meliputi formula-formula, pola, formula atau bahan kimia, proses industri, perawatan atau pengawetan bahan-bahan, pola mesin atau alat lain, daftar langganan atau alat kompilasi informasi yang digunakan seseorang dalam bisnisnya dan yang mana memberikan orang tersebut kesempatan untuk memper- oleh keuntungan melebih dari siangannya yang tidak tahu atau tidak menggunakan itu. Termasuk juga rencana atau proses, peralatan/ perkakas atau bahan mesin yang hanya diketahui olehnya dan pegawainya yang perlu disampaikan.

Fenomena globalisasi yang terjadi pada akhir abad ke 20 yang diperkirakan akan terus berlangsung sampai abad ke-21 adalah transparansi, liberalisasi dan privatisasi, yang arus diterima masyarakat dunia, termasuk indonesia, sebagai suatu realitas yang mendorong tuntutan untuk dilakukannya penyesuaian, baik struktur, organisasi maupun sistem yang ada, termasuk sistem ekonomi dan sistem hukum.

$$
\text { Marwah M. Diah }
$$

menjelaskan bahwa fenomena transparansi berarti suatu negara arus membuka diri dan semua kebijakan serta tindakan harus bersifat terbuka, sedangkan liberalisasi berarti dilakukan upaya pengurangan atau bahkan kalau mungkin menghilangkan berbagai hambatan baik tarif maupun non tarif dalam kegiatan perdagangan

${ }^{1}$ Henry Campbell Black, M.A, Black's Law Dictionary With Pronunciations, Sixth Edition, St. Paul, Minn - West Publishing co- 1990, h. 1494. barang dan jasa antarnegara. Adapun privaitisasi dalam arti umum bertujuan mengurangi peranan pemerintah dan pemberian kesempatan yang lebih besar kepada swasta dalam pengelolaan sektor perekonomian. ${ }^{2}$

$$
\text { Restrukturisasi bidang }
$$

hukum menurut David Trubek, merupakan kebutuhan yang mendesak dalam menghadapi perubahan ekonomi global, karena sektor hukum dan sektor ekonomi adalah dua faktor yang saling berhubungan dan saling empengaruhi. Hukum (modern) adalah penting dalam menciptakan dan mempertahankan pasar. ${ }^{3}$

Sunaryati Hartono menjelaskan bahwa hukum dan ekonomi mempunyai pengaruh timbal-balik. Jika pada satu piak pembaruan dasar-dasar pemikiran di bidang ekonomi ikut mengubah dan menentukan dasar-dasar sistem hukum yang bersangkutan, maka penegakan asas asas hukum yang sesuai juga kan memperlancar terbentuknya struktur ekonomi yang dikehendaki. Sebaliknya, penagakan asas-asas hukum yang tidak sesuai justru akan mengambat terciptanya struktur ekonomi yang dicita-citakan. $^{4}$

Memperhatikan perubaan sistem ekonomi global dan mencermati sifat hubungan antara hukum dan ekonomi, maka pembaruan sektor hukum adalah kebutuhan yang mendesak dalam menghadapi perubahan ekonom global tersebut. Pembaruan hukum, khususnya hukum di bidang ekonomi, perlu dilakukan karena

\footnotetext{
${ }^{2}$ Muhammad Syaifuddin, Annalisa Yahanan dan Yunial Laili Mutiari, Desain Industri Perspektif Filsafat, Teori dan Dogmatik Hkum, Tunggal Mandiri, Malang, 2009, hlm, 1-2

${ }^{3}$ Ibid, hlm 2

${ }^{4}$ ibid
} 
Susi Yanuarsi, Perlindungan Hukum Terhadap Pemilik Rahasia Dagang Yang Bersifat Komersil, halaman 122-131

indonesia telah meratifikasi perjanjian WTO berdasarkan Undang-Undang No. 7 tahun 1994.

Sesuai dengan pasal 11 Konvensi Wina Tahun 1986, ratifikasi perjanjian WTO berdasarkan UU No. 7 tahun 1994 berakibat hukum indonesia terikat dengan perjanjian internasional itu dan sekaligus secara resmi menjadi anggota WTO. Jika dikaitkan dengan Hukum hak kekayaan intelektual, maka HKI indonesia harus diselaraskan dengan general Agrement on Trade Related Aspects of intelectual property rights (TRIPs).

Indonesia adalah negara yang secara normatif mempunyai aturan hukum positif pada level undang-undang lengkap dibidang HKI. Pembentukan aturan-aturan hukum positi dibidang HKI di indonesia adalah konsekuensi yuridis dari keikutsertaan indonesia sebagai anggota dan secara sah ikutserta dalam TRIPs melalui ratifikasi perjanjian WTO berdasarkan UU No. 7 tahun 1994.

Dengan telah diratifikasi Agreement Establising teh Word Trade Organization (persetujuan pembentukan Organisasi Perdagangan Dunia (WTO) yang mencakup TRIPs dengan UndangUndang No. 7 tahun 1994, sehingga perlu diatur mengenai Rahasia dagang. Tujuan pengaturan Rahasia dagang adalah utuk memajukan industri yang mampu bersaing dalam lingkup perdagangan nasional dan internasional perlu iklim yang mendorong kreasi dan inovasi masyarakat dengan memberikan perlindungan hukum terhadap Rahasia dagang sebagai bagian dari sistem Hak atas kekayaan Intelektual. ${ }^{5}$

Respon

pemerintah terhadap ratifikasi tersebut pada tahun 2000 diberlakukan UndangUndang No. 30 tahun 2000 tentang rahasia Dagang. Berdasarkan ketentuan pasal 1 angka 1, Rahasia dagang adalah informasi yang tidak diketahui oleh umum di bidang teknologi dan/atau bisnis, mempunyai nilai ekonomis karena berguna dalam kegiatan usaha, dan dijaga kerahasiannya oleh pemilik Dagang rahasia.

\section{B. Permasalahan}

1. Bagaimana perlindungan hukum terhadap pemilik rahasia Dagang?

2. Apa akibat hukum terhadap pemegang rahasia dagang yang membocorkan kerahasian rahasia dagang?

\section{PEMBAHASAN}

Perkembangan Hak atas Kekayaan Intelektual di ndonesia tampak sejak awal dasawarsa tahun 80-an, terutama dibidang ekonomi, khususnya industri dan perdagangan internasional. Para pemilik HaKI mulai melakukan pendaftaran hak Cipta, Merek dan paten pada Direktorat Jenderal HaKI Departemen Kehakiman. Tumbuhnya kesadaran melakukan pendaftaran HaKI ini menunjukan bahwa pentingya perlindungan hukum teradap pemilik HaKI dalam kegiatan Bisnis

Untuk menghindari persaingan tidak wajar (curang), maka diperlukan perlindungan terhadap HaKI dari pemalsuan dan penciplakan dari berbagai jenis HaKI yang dilindungi oleh

\footnotetext{
5 Joni Emirzon, Hukum Bisnis Indonesia, Literata, Jakarta, 2008, hlm. 356
} 
Susi Yanuarsi, Perlindungan Hukum Terhadap Pemilik Rahasia Dagang Yang Bersifat Komersil, halaman 122-131

Undang-Undang. Untuk memproteksi kemungkinan itulah, pemilik teknologi informasi bisnis yang memiliki nilai ekonmis lebih cenderung mendaftarkan haknya sebagai Rahasia Dagang daripada mendaftarkannya sebagai paten atau berdasarkan perlindungan hak cipta. Tujuannya adalah agar hak itu dapat dipergunakan lebih lama dan dengan demikian pemilik dapat lebih panjang menikmati keuntungan dan sekaligus memproteksi produknya dari unsur peniruan.

Di negara-negara yang menganut sistem hukum anglo saxon, informasi dianggap sebagai hak kekayaan (property rights) dan pelanggarannya diklasifikasikan sebagai perbuatan melawan hukum yang bersifat khusus yang disebut the action for breach of confidence, sedangkan di negar-negara yang menganut sistim gukum civil law, pelanggaran semacam itu hanya dianggap sebagai perbuatan onrechtsmatiggedaad, perbuatan melawan hukum biasa. ${ }^{6}$

Batasan pengertian rahasia dagang secara normatif dirumuskan sebagai informasi yang tidak diketahui oleh umum di bidang teknologi dan/atau bisnis mempunyai nilai ekonomis karena berguna dalam kegiatan usaha, dan dijaga kerahasiannya oleh pemilik Rahasia dagang.

Jika dicermati unsur-unsur yang termaktub dalam definisi tersebut di atas, maka dapat ditarik karakteristik hukum rahasia dagang yakni:

1. merupakan informasi
yang tidak diketahui umum

\footnotetext{
${ }^{6}$ OK. Saidin, Aspek Hukum Hak Kekayaan Intelektual (Intelectual Property Rights),PT. RajaGrafindo Persada ,Jakarta, 2010, hlm, 452.
}

2. informasi itu meliputi bidang teknologi atau bisnis

3. mempunyai nilai ekonomis yang berguna dalam kegiatan usaha.

4. Dijaga kerahasiannya

Perlindungan HKI yang secara essensial adalah hak eksklusif dan tidak dapat dipungkiri memang akan menimbulkan monopoli. Akan tetapi monopoli ini bukan berarti selalu menimbulkan hal yang negatif. Monopoli ini hanya berlangsung untuk jangka waktu dan dengan syarat-syarat tertentu. Menurut Mahkamah Agung AS dalam putusan Zenith Radio Corp. $\mathrm{v}$ Hazeline Research, Inc. mengatakan bahwa : "The heart of legal monopoli is the right to invoke the state's power to prevent other from utilizing his discovery with out his consent." (Inti pengesahan monopoli adalah hak memohon kewenangan negara untuk mencegah pihak lain memanfaatkan atau menggunakan penemuannya tanpa persetujuan).

Di beberapa Negara, konsep atau informasi yang mendapat perlindungan Rahasia Dagang, adalah. ${ }^{8}$

-. daftar pelanggan;

- penelitian pasar atau penelitian teknis;

- resep masakan atau ramuan yang digunakan untuk menghasilkan sebuah produk tertentu;

- sistem kerja tertentu yang cukup menguntungkan;

- ide atau konsep yang mendasari kampanye pengiklanan atau pemasaran;

7 Achmad Zen Umar Purba, Hak

Kekayaan Intelektual Pasca TRIPs, Alumni, Bandung, 2005, hlm.14.

${ }^{8}$ Tim Lindsey, et all, Hak Kekayaan Intelektual Suatu Pengantar, Alumni, Bandung, 2006, hlm, 236 
- informasi keuangan atau daftar harga yang menunjuk- kan marjin laba dari sebuah produk;

- sebuah cara untuk mengubah atau menghasilkan sebuah produk dengan menggunakan kimia atau mesin.

Kepemilikan dan perlindungan atas suatu informasi rahasia yang dikategorikan sebagai rahasia dagang dan merupakan intangible aset dari suatu perusahaan, terjadi secara otomatis. Siapa yang menemukan atau membuat rahasia dagang tersebut, maka otomatis oleh undang-undang dialah dianggap sebagai pemiliknya dan berdasarkan Pasal 4 UU No. 30 / 2000, pemilik ini berhak melarang penggunaan atau pengungkapan tanpa izinnya yang dila- kukan seseorang kepada pihak ketiga untuk kepentingan yang bersifat komersial. Dalam kasus Fireworks Spectacular, Inc and Piedmont Display Fireworks, Inc $v$ Premier Pyrotechnics, Inc and Matthew P. Sutcliffe 2000 U.S. Dist. LEXIS 2362. ${ }^{9}$ data pelanggan (customer list) Fireworks Spectacular Inc and Piedmont Display Fireworks, Inc yang dibuat dalam logbook dianggap sebagai rahasia dagang karena data pelanggan dalam bidang mercon tidak mudah diperoleh. Butuh jangka waktu yang lama, bahkan sampai bertahun-tahun sehingga data pelanggan dapat dikompilasi. Oleh karena itu Pihak Fireworks menganggap data pelanggan tersebut memberikan nilai komersial yang sangat tinggi. Sebagai pemilik, Fireworks berhak menuntut ganti rugi dan mela-rang penggunaan maupun pengungkapan yang dilakukan seseorang kepada pihak ketiga untuk kepentingan yang bersifat komersial.

Perlindungan terhadap gagasangagasan yang mempunyai nilai komersial dan memberikan

\footnotetext{
${ }^{9}$ Gunawan Widjaja, Rahasia Dagang, Raja
} Grafindo Perada, jakarta, 2001.hlm, 35 keuntungan bersaing, dapat mendorong iklim yang sehat dan memantapkan hubungan para pihak dalam transaksi perdagangan. Berdasarkan National Science Foundation, Science and Engineering Indicators, tahun 1991, penerimaan total Amerika Serikat dari perdagangan HKI mendekati 18 milyar dolar Amerika. Selama periode tahun 1987 sampai 1991, perusahaanperusahaan menerima empat sampai lima kali jumlah pembayaran dari perusahaanperusahaan luar negeri. Hal ini menunjukkan rahasia dagang memiliki nilai yang sangat penting dalam dunia investasi dan perdagangan. Oleh karena itu diperlukan perlindungan terhadap rahasia dagang agar informasi bisnis yang sifatnya sangat strategis dan kompetitif yang tidak terlindungi dengan sistem hukum HKI lainnya, misalnya hak paten atau hak cipta atau hak disain, dapat dilindungi. Untuk memperoleh perlindungan paten, seorang penemu (inventor) harus menemukan sesuatu yang sifatnya baru (novelty), memenuhi syarat langkah inventif, dapat diterapkan dalam industri dan didaftarkan. Misalnya penemuan suatu metode produksi dari teknologi cara penghancur sampah yang sangat cepat kemudian dituangkan dalam bentuk alat yang berwujud. Agar ide dan alatnya ini dapat dilindungi, maka bisa didaftarkan sebagai hak paten. Sedangkan rahasia dagang dapat dilakukan secara lebih fleksibel karena tidak diperlukan pendaftaran untuk mendapat eksistensinya. Umumnya perlindungan atas HKI meliputi ide hasil kerja otak atau hasil kerja rasio yang dengan jerih payah diperoleh dari keahlian khusus 
pemiliknya. Oleh karenanya selain ide kerja otak atau ide kerja ratio maka wajud nyata dari HKI tersebut juga dilindungi, kecuali rahasia dagang. Khusus untuk rahasia dagang, perlindungan hukum hanya terbatas pada konsep atau ide yang dihasilkan oleh kerja otak atau kerja ratio yang dirahasiakan, bukan melindungi wujud nyata dari rahasia dagang tersebut. Oleh karena itu rahasia dagang tidak perlu didaftarkan untuk memperoleh perlindungan tetapi secara otomatis langsung terlindungi dan sudah diakui kepemilikannya oleh negara.

Adanya pengaturan rahasia dagang dalam TRIPs menunjukkan bahwa telah ada kesepakatan, minimal bagi anggota peserta WTO, bahwa tanpa membuat kontrak mengenai kewajiban meraha-siakan suatu informasi yang berharga dengan pihak lain dalam berbisnis, otomatis rahasia dagangnya telah dilindungi. Perlindungan rahasia dagang dalam suatu negara akan mendorong masuknya investasi, inovasi industri dan kemajuan teknologi. Para investor merasa aman dan dihargai karena ada perlindungan atas rahasia dagangnya dan akan berpengaruh langsung pada keseluruhan perekonomian negara. Perlindungan ini didasarkan pula pada adanya perkembangan kebijakan dan kepedulian mengenai perlindungan aset-aset intelektual atau HKI, termasuk rahasia dagang. yang dilan-dasi oleh beberapa teori, yaitu Teori Reward, Teori Recovery, Teori Incentive, Teori risk dan Economic Growth Stimulus Theory.

Menurut teori reward, pencipta di bidang ilmu pengetahuan, seni dan sastra, serta penemu di bidang teknologi baru yang mengandung langkah inovatif serta dapat diterapkan dalam industri, harus diberikan suatu penghargaan dan pengakuan serta perlindung- an hukum atas keberhasilan upayanya dalam melahirkan ciptaan baru itu.

Teori recovery beranggapan bahwa usaha dari pencipta dan penemu yang telah mengeluarkan tenaga, pikiran, waktu dan biaya yang tidak sedikit jumlahnya dalam menghasilkan karya intelektualnya maka harus diberikan kepadanya hak eksklusif untuk meng- eksploitasi HKI guna meraih kembali apa yang telah dikeluarkan-nya. Sedangkan menurut teori incentive, pencipta dan penemu akan diberikan Insentif untuk merangsang kreativitas dan upaya mencip-takan karya-karya baru di bidang teknologi. Untuk menarik upaya dan dana bagi pelaksanaan serta pengembangan kreativitas penemu agar menghasilkan sesuatu yang baru, maka diperlukan adanya suatu insentif yang dapat memacu terjadinya kegiatan penelitian.

Penghargaan yang diberikan berdasarkan teori-teori di atas bukan satu-satunya upaya memberikan keuntungan bagi penemunya akan tetapi bertujuan untuk menumbuhkan kreativitas masyarakat bahkan untuk menemukan kreativitas secara nasional. Pemberian penghargaan tersebut merupakan sumbangan konkrit bagi negara dalam pembangunan teknologi dan pembangunan ekonominya. Teori ini dina-makan Teori Kepentingan Makro.

Selanjutnya ada pula yang dinamakan teori risk yang mengakui bahwa HKI merupakan suatu hasil karya atau 
penelitian yang mengandung resiko karena ada kemungkinan orang lain yang terlebih dahulu menemukan cara tersebut atau memperbaikinya, sehingga dengan demikian adalah wajar untuk memberikan perlin-dungan hukum terhadap upaya atau kegiatan yang mengandung resiko tersebut. Dengan adanya perlindungan maka resiko yang timbul dari penggunaan secara ilegal dan mengakibatkan kerugian secara ekonomis maupun moral bagi penemu dapat dihindari jika terdapat landasan hukum yang kuat untuk melindungi HKI tersebut.

Selain teori-teori diatas juga dikenal adanya Economic Growth Stimulus Theor_Teori ini mengakui bahwa perlindungan atas HKI adalah suatu alat dari pembangunan ekonomi yang ber-tujuan membangun suatu sisem perlindungan atas hak kekayaan intelektual yang efektif. Adanya teori ini mendorong usaha dan pengembangan komersial dengan menjamin pihak pengusaha mengembangkan konsep, pengetahuan dan informasi daripada hanya mencuri atau meniru kekayaan pihak lain. Teori ini dikenal di nega- ra-negara berkembang dengan nama "public benefit" atau "econo mic growth stimulus", atau "social rate of return" atau bahkan teori "more things will happen"

Informasi tidak diketahui umum, bermakna bahwa informasi itu bersifat ekselusif, hanya si pemegang informasi tersebut sajalah yang dapat mengetahui rahasia itu. Rahasia yang berisikan informasi bidang teknologi atau yang ada kaitannya dengan dunia bisnis.

Informasi teknologi, sudah barang tentu untuk memperolehnya melalui kajian ilmiah yang memerlukan kecerdasan intelektual, biaya dan mungkin mengabiskan waktu yang panjang. Oleh karena itu berguna bagi dunia bisnis, maka pastilah mempunyai nilai ekonomis, karena itu kerahsiaan perlu dijaga oleh pemiliknya.

Dasar

filosofis

perlindungan informasi yang dirahasiakan itu adalah karena informasi tersebut diperoleh oleh pemiliknya dengan jerih payah dan memerlukan keahlian khusus, menghabiskan banyak waktu dan biaya, sama seperti perlindangan HaKI lainnya, meskipun tidak selamanya demikian. Adanya juga informasi itu diperoleh dengan cara yang sangat sederhana, tetapi bagaimanapun juga itu tetap merupakan hak yang harus dihormati.

Dasar pemikiran untuk melindungi informasi rahasia dagang di bersetujuan TRIPs adalah sama dengan dasar pemikiran untuk perlindungan bentuk HaKI yang lain, seperti hak cipta, Paten Desan atau merek. Yaitu untuk menjamin pihak yang melakukan investasi untuk mengembagkan konsep, ide dan informasi yang bernilai komersial dapat menfaat dari investasi itu dengan memperoleh hak ekskusif untuk menggunakan konsep atau informasi, maupun untuk mencegah pihak lain menggunakannya atau mengungkapkan tanpa izin.

$$
\text { Lingkup perlindungan }
$$
rahasia dagang meliputi metode produksi, metode pengolahan, metode penjualan atau informasi lain di bidang teknologi dan/atau bisnis yang memiliki nilai ekonomi 
dan tidak diketahui oleh masyarakt umum. Pemilik rahasia dagang dapat memberikan lisensi bagi pihak lain. Yang dimaksud dengan lisensi adalah izin yang diberikan kepada pihak lain melalui suatu perjanjian berdasarkan pada pemberian hak (bukan pengalihan hak) untuk menikmati manfaat ekonomi dari suatu rahasia dagang yang diberikan perlindungan pada jangka waktu tertentu dan syarat tertentu.

Tidak dianggap sebagai
pelanggaran rahasia dagang
apabila: (1) mengungkap untuk
kepentingan Hankam, kesehatan
atau keselamatan masyarakat. (2)
rekayasa ulang atas produk yang
dihasilkan oleh pengguna rahasia
dagang milik orang lain yang
dilakukan semata-mata untuk
kepentingan pengembngan lebih
lanjut produk yang bersangkutan

\section{Lingkup Rahasia Dagang}

a. Subyek Rahasia dagang adalah pemilik rahasia dagang.

Pemilik rahasia dagang memiliki hak untuk :

1. Menggunakan sendiri Rahasia Dagang yang dimilikinya

2. Memberi lisensi kepada pihak lain atau melarang pihak lain untuk menggunakan Rahasia Dagang atau mengungkapkan Rahasia Dagang itu kepada pihak ketiga untuk kepentingan yang bersifat komersial

b. Obyek ruang lingkup rahasia dagang menurut undangundang No. 30 Tahun 2000 Pasal 2 meliputi metode produksi, metode pengolahan, metode penjualan atau informasi lain di bidang tekhnologi dan/atau bisnis yang memiliki nilai ekonomi dan tidak diketahui oleh masyarakat umum

c. LamaPerlindungan

Beberapa alasan/keuntungan penerapan Rahasia Dagang dibandingkan Paten adalah karya intelektual tidak memenuhi persyaratan paten, masa perlindungan yang tidak terbatas, proses perlindungan tidak serumit dan semahal paten, lingkup dan perlindungan geografis lebih luas.Namun, tanpa batas waktu ini mempunyai syarat yaitu sebagaimana tercantum dalam Pasal 3 yaitu bahwa rahasia dagang dilindungi bila informasi tersebut masih bersifat rahasia, mempunyai nilai ekonomi, dan dijaga kerahasiaannya melalui upaya semestinya. Ketiga syarat yang harus dipenuhi itu dapat diuraikan sebagai berikut.

1. Bersifat rahasia apabila informasi itu hanya diketahui oleh orang-orang terbatas.

2. Informasi mempunyai nilai ekonomi apabila sifat kerahasiaan informasi tersebut dapat digunakan untuk menjalankan kegiatan usaha atau bisnis yang komersial atau mendatangkan keuntungan bagi pemiliknya.

3. dijaga kerahasiaannya apabila pemilik atau para pihak yang menguasainya telah melakukan langkahlangkah yang layak. ${ }^{10}$ 
Pencipta informasi akan perlu memperlihatkan bahwa penerima menggunakan konsep atau informasi tanpa izin dari pencipta. Ada dua bentuk penggunaan tanpa izin:

1. Di mana pencipta informasi tidak memberikan izin kepada pengguna sama sekali.

2. Di mana pencipta informasi mengizinkan penerima menggunakan informasi untuk tujuan tertentu, tetepai si penerima informasi telah menggunakan informasi itu untuk tujuan lain dicakupan izin yang diberikan. ${ }^{11}$

Bukti biasanya diperlukan untuk membuktikan cara yang tepat bagaimana informasi rahasia dagang telah disalahgunakan. Pelanggaran Rahasia Dagang terjadi apabila seseorang dengan sengaja mengungkapkan Rahasia Dagang, mengingkari kesepakatan atau mengingkari kewajiban tertulis atau tidak tertulis untuk menjaga Rahasia Dagang yang bersangkutan. ${ }^{12}$ Untuk mengatasi adanya pelanggaran tersebut maka amat diperlukan perlindungan hukum bagi pemilik dan atau pemegang HAKI yang bersangkutan Setelah terbukti informasi tersebut bersifat rahasia dan bahwa informasi itu diberikan atau diperoleh tergugat, penggunaan informasi sulit dibuktikan secara langsung, tetapi mudah dilihat dari tindakan tergugat Apabila seseorang merasa pihak lain telah melanggar hak Rahasia Dagang yang dimilikinya, maka ia sebagai pemegang hak

\footnotetext{
${ }^{11}$ Bambang Kesowo. 1995. Pengantar Hak Atas

Kekayaan Intelektual. UGM-Yogyakarta. hlm. 10

${ }^{12}$ H. OK. Saidin, S.H., M. Hum. Op. Cit, hlm. 464
}

Rahasia Dagang atau pihak lain sebagai penerima lisensi dapat menggugat siapapun yang dengan sengaja dan tanpa hak Rahasia Dagang maka kita dapat mengajukan gugatan ke Pengadilan Negeri. Gugatan yang kita ajukan dapat berupa gugatan ganti rugi dan / atau penghentian semua perbuatan. Disamping itu juga dapat ditempuh upaya lain yakni melalui penyelesaian sengketa melalui Arbitrase atau Alternatif Penyelesaian Sengketa (ADR).

Perlindungan hukum pemilik rahasia dagang yang rhasia dagang miliknya dilanggar dapat melaporkan secara pidana Barangsiapa dengan sengaja dan tanpa hak menggunakan dan mengungkapkan Rahasia Dagang, mengingkari kesepakatan atau mengingkari kewajiban tertulis atau tidak tertulis untuk menjaga Rahasia Dagang yang bersangkutan, atau pihak lain yang memperoleh/menguasai Rahasia Dagang tersebut dengan cara yang bertentangan dengan peraturan perundang-undangan yang berlaku, dipidana dengan pidana penjara paling lama 2 (dua) tahun dan/atau denda paling banyak Rp $300.000 .000,00$ (tiga ratus juta rupiah).

\section{KESIMPULAN}

Dari uraian tersebut diatas, maka dapat ditarik kesimpulan

1. Lingkup perlindungan rahasia dagang meliputi metode produksi, metode pengolahan, metode penjualan atau informasi lain di bidang teknologi dan/atau bisnis yang memiliki nilai ekonomi dan tidak diketahui oleh masyarakt umum.dengan demikian perlindungan hukum rahasia dagang hanya terbatas pada 
konsep atau ide yang dihasilkan oleh kerja otak atau kerja ratio yang dirahasiakan, bukan melindungi wujud nyata dari rahasia dagang tersebut. Oleh karena itu rahasia dagang tidak perlu didaftarkan untuk memperoleh perlindungan tetapi secara otomatis langsung terlindungi dan sudah diakui kepemilikannya oleh negara. Disamping itu juga perlindungan rahasia dagang tidak terbatas waktunya sepanjang rahasia dagang tersebut tidak diketahui oleh umum.

2. Apabila seseorang merasa pihak lain telah melanggar hak Rahasia Dagang yang dimilikinya, maka ia sebagai pemegang hak Rahasia Dagang atau pihak lain sebagai penerima lisensi dapat menggugat siapapun yang dengan sengaja dan tanpa hak Rahasia Dagang maka kita dapat mengajukan gugatan ke Pengadilan Negeri. Gugatan yang kita ajukan dapat berupa gugatan ganti rugi dan / atau penghentian semua perbuatan. Barangsiapa dengan sengaja dan tanpa hak menggunakan dan mengungkapkan Rahasia Dagang, mengingkari kesepakatan atau mengingkari kewajiban tertulis atau tidak tertulis untuk menjaga Rahasia Dagang yang bersangkutan, atau pihak lain yang memperoleh/menguasai

Rahasia Dagang tersebut dengan cara yang bertentangan dengan peraturan perundangundangan yang berlaku, dipidana dengan pidana penjara paling lama 2 (dua) tahun dan/atau denda paling banyak Rp 300.000.000,00 (tiga ratus juta rupiah). Disamping itu juga dapat ditempuh upaya lain yakni melalui penyelesaian sengketa melalui Arbitrase atau Alternatif Penyelesaian Sengketa (ADR).

\section{DAFTAR PUSTAKA}

Achmad Zen Umar Purba, Hak Kekayaan Intelektual Pasca TRIPs, Alumni, Bandung, 2005,

Bambang Kesowo. Pengantar Hak Atas Kekayaan Intelektual. UGMYogyakarta.1995.

Gunawan Widjaja, Rahasia Dagang, Raja Grafindo Perada, jakarta, 2001.hlm

Joni Emirzon, Hukum Bisnis Indonesia, Literata, Jakarta, 2008.

Henry Campbell Black, M.A, Black's Law Dictionary With Pronunciations, Sixth Edition, St. Paul, Minn - West Publishing co- 1990, h. 1494.

Muhammad Syaifuddin, Annalisa Yahanan dan Yunial Laili Mutiari, Desain Industri Perspektif Filsafat, Teori dan Dogmatik Hukum, Tunggal Mandiri, Malang, 2009.

OK. Saidin, Aspek Hukum Hak Kekayaan Intelektual (Intelectual Property Rights),PT. RajaGrafindo Persada ,Jakarta, 2010.

Tim Lindsey, et all, Hak Kekayaan Intelektual Suatu Pengantar, Alumni, Bandung, 2006.

Undang-Undang Nomor 30 Tahun 2000 tentang Rahasia Dagang 